\section{Scientific journal}

\section{PHYSICAL AND MATHEMATICAL EDUCATION}

Has been issued since 2013.

Науковий журнал

ФІЗИКО-МАТЕМАТИЧНА ОСВІТА

Видається 32013.
ISSN 2413-158X (online)

ISSN 2413-1571 (print)

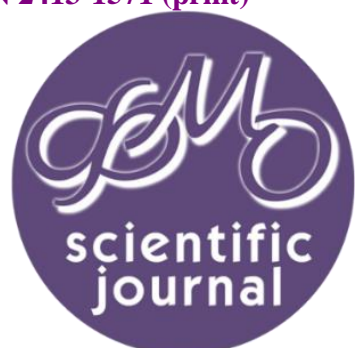

Аль-Амморі А.Н., Іщенко Р.М. Міжпредметні зв'язки фізики з дисциплінами циклу професійної підготовки майбутніх фрахівців з інформаційної безпеки. Фізико-математична освіта. 2021. Випуск 2(28). С. 22-28.

Al-Ammouri A., Ishchenko R. Intersubject connections of physics with disciplines of the cycle of professional training of future informational security specialists. Physical and Mathematical Education. 2021. Issue 2(28). P. 22-28.

DOI 10.31110/2413-1571-2021-028-2-004

Удк $378.1 ; 378.9$

А.Н. Аль-Амморі

Національний транспортний університет, Україна ammourilion@ukr.net

ORCID: 0000-0002-0375-6108

Р.М. Іщенко

Національний транспортний університет, Україна rm_ischenko@ukr.net

ORCID: 0000-0003-0158-4020

\title{
МІЖПРЕДМЕТНІ ЗВ'ЯЗКИ ФІЗИКИ З ДИСЦИПЛІНАМИ ЦИКЛУ ПРОФЕСІЙНОЇ ПІДГОТОВКИ МАЙБУТНІХ ФАХІВЦІВ 3 ІНФОРМАЦІЙНОЇ БЕЗПЕКИ
}

АНОТАЦІЯ

Формулювання проблеми. Швидкий розвиток інформаційних технологій, становлення та розвиток інформаційного суспільства обумовлюють виникнення питання щодо інформаційної безпеки. Відповідно до иього, підготовка квалірікованих фахівців з інформаційної безпеки на даний час є актуальною. Необхідно відзначити, що рівень підготовки вказаних фахівиів значною мірою залежить від належного опанування ними фундаментальних дисциплін, зокрема, фізики. Тому дана робота присвячується встановленню міжпредметних зв'язків фізики з дисциплінами циклу професійної підготовки майбутніх фахівців з інформаційної безпеки.

Матеріали і методи. Для досягнення поставленої мети роботи використовувалися наступні методи: аналіз і систематизація під час огляду наукових публікацій за обраною тематикою дослідження; аналіз, порівняння, систематизація, узагальнення - під час встановлення міжпредметних зв'язків фізики з дисциплінами циклу професійної підготовки майбутніх фахівців з інформаційної безпеки, обговорення результатів дослідження та формулювання висновків роботи.

Результати. 3 проведеного аналізу освітньо-професійних програм підготовки бакалаврів з інформаційної безпеки, які розроблені різними закладами вищої освіти, виявлено, що під час освітнього процесу враховуються хронологічні міжпредметні зв'язки фізики з дисциплінами циклу професійної підготовки. Проаналізовано програми з фізики та дисциплін циклу професійної підготовки зазначених фахівців та вибрано ті з них, під час вивчення яких використовуються теми з тих чи інших розділів курсу фізики. Встановлено зв'язок фізики з дисциплінами циклу професійної підготовки майбутніх фахівців з інформаційної безпеки.

Висновки. За результатами аналізу програм з фізики та дисциплін циклу професійної підготовки майбутніх фрахівців з інформаційної безпеки встановлено, що для успішного опанування ряду дисциплін циклу професійної підготовки необхідно мати належний рівень знань, умінь і навичок з усіх розділів курсу фізики рівня технічного університету. Встановлено, що врахування міжпредметних зв'язків фізики з дисциплінами циклу професійної підготовки зазначених фахівців призводить до підвищення успішності студентів та їх мотивації до навчання, що, в свою чергу, підвищує ефективність освітнього процесу в закладах вищої освіти.

КлЮчОВІ СлОВА: міжпредметні зв'язки, курс фізики, дисципліни професійної підготовки, фахівець з інформаційної безпеки, технічний університет.

ВСТУП

Постановка проблеми. Швидкий розвиток інформаційних технологій, які впроваджуються в усі сфери людської діяльності, становлення та розвиток інформаційного суспільства (Сопілко, 2017) обумовлюють виникнення питання щодо інформаційної безпеки. У зв'язку з цим, крім ефективного опрацювання та оперативної передачі інформаційних даних, виникає проблема, пов'язана з організацією надійного захисту та зберігання інформації. Саме тому підготовка 
кваліфікованих фахівців з аудиту, організації та управління інформаційною безпекою (Безуглий, 2018; Рой, Мазур \& Складанний, 2018) на даний час $€$ актуальною. Необхідно відзначити, що рівень підготовки вказаних ІT-фахівців значною мірою залежить від належного опанування ними фундаментальних дисциплін. Однією з таких дисциплін $є$ фізика, яка відноситься до циклу обов'язкових навчальних дисциплін математичної і природничо-наукової підготовки, що вивчаються студентами технічних університетів. Загальні і професійні компетентності, набуті під час вивчення фізики, сприяють формуванню наукового світогляду і наукового стилю мислення студентів та $\epsilon$ основою для подальшого успішного опанування багатьох навчальних дисциплін, які входять до циклу професійної підготовки майбутніх фахівців 3 інформаційної безпеки. У той же час фізика $є$ традиційно однією з найскладніших дисциплін для більшості студентів (Іщенко \& Ісаєнко, 2020). Крім того, багато студентів не усвідомлюють повною мірою мети вивчення складних фундаментальних дисциплін, до числа яких входить фізика, вважаючи їх «непотрібними». Останнє негативно впливає на мотивацію студентів до вивчення фізики та, як наслідок, на рівень підготовки з вказаної дисципліни та ряду дисциплін циклу професійної підготовки, під час вивчення яких безпосередньо використовується теоретичний матеріал тих чи інших розділів курсу фізики. Відповідно до цього, проблема встановлення міжпредметних зв'язків фізики з дисциплінами циклу професійної підготовки майбутніх фахівців з інформаційної безпеки та їх реалізація з метою підвищення ефективності освітнього процесу $є$ достатньо актуальною.

Аналіз актуальних досліджень. Проблемі міжпредметних зв'язків фізики з математикою, інформатикою, іншими природничими, загальнотехнічними і фаховими дисциплінами та ї реалізації в освітньому процесі присвячено значну кількість наукових робіт. Вказаним напрямком дослідження займалися Атаманчук П.С., Богданов І.Т., Бугайов О.І., Гончаренко С.У., Дідик А.О., Збаравська Л.Ю., Ільніцька К.С., Касперський А.В., Кислова М.А., Матвійчук О.В., Пастушенко С.М., Подласов С.О., Сергєєв О.В., Сергієнко В.П., Слєпкань 3.І., Шут М.І. та інші вчені. Зокрема, у роботі (Матвійчук, Сергієнко \& Подласов, 2008) показано можливість реалізації міжпредметних зв'язків фізики та інформатики під час комп'ютерного моделювання фізичних процесів. У роботі (Ільніцька, 2020) досліджено міжпредметні зв'язки фізики з інформатикою і електронікою та розглянуто особливості вивчення робототехніки майбутніми учителями фізики в межах дисципліни «Основи сучасної електроніки». У роботі (Дідик, 2019) визначено місце і роль загальної фізики, вищої математики, хімії та технічної механіки у процесі вивчення електротехніки та електроніки. Відзначено, що реалізація міжпредметних зв'язків сприяє більш глибокому засвоєнню вказаної дисципліни, усуває дублювання під час вивчення матеріалу, заощаджує час і створює сприятливі умови для формування фахових компетентностей. У науково-педагогічній літературі знайдено ряд робіт, в яких встановлено роль міжпредметних зв'язків математичних дисциплін з дисциплінами циклу професійної підготовки IT-фахівців. Зокрема, в роботі (Коржова, 2017) визначено місце і роль математичної освіти у системі професійної підготовки майбутніх фахівців з кібербезпеки.

Важливість встановлення міжпредметних (міждисциплінарних) зв'язків та їх реалізації в освітньому процесі підкреслюється і в закордонній педагогічній літературі. Зокрема, у роботі (Zeynep Başkan, Nedim Alev \& Işik Saliha Karal, 2010) відзначено доцільність впровадження міждисциплінарного викладання фізики і математики та запропоновано організовувати курси підвищення кваліфікації без відриву від виробництва для викладачів з метою підготовки останніх до міждисциплінарного викладання вказаних навчальних предметів. У роботі (Lei Bao \& Kathleen Koenig, 2019) відзначено, що процес міждисциплінарної інтеграції знань з фізики, математики та загальнотехнічних дисциплін може розглядатися як один із засобів підвищення ефективності освітнього процесу. Взагалі, роль міждисциплінарності в освітньому процесі та наукових дослідженнях постійно зростає, починаючи з середини 80-х років XX століття (Richard Van Noorden, 2015).

Однак, незважаючи на значну кількість робіт, в яких досліджено міжпредметні зв'язки фізики з іншими дисциплінами, у науково-педагогічній літературі не знайдено робіт, присвячених проблемі встановлення міжпредметних зв'язків фізики з дисциплінами циклу професійної підготовки майбутніх IT-фахівців, зокрема, фахівців з інформаційної безпеки, що актуалізує мету представленої роботи.

Мета статті. Враховуючи вищезазначене, мета статті полягає у встановленні міжпредметних зв'язків фізики 3 дисциплінами циклу професійної підготовки майбутніх фахівців з інформаційної безпеки, що навчаються в технічному університеті.

\section{МЕТОДИ ДОСЛІДЖЕННЯ}

Для досягнення поставленої мети роботи використовувалися наступні методи: аналіз і систематизація наукових статей, навчально-методичних розробок, присвячених дослідженню міжпредметних зв'язків фізики з математикою, інформатикою, іншими природничими, загальнотехнічними і фаховими дисциплінами та їх реалізації в освітньому процесі; аналіз освітньо-професійних програм підготовки бакалаврів з інформаційної безпеки, розроблених різними закладами вищої освіти (ЗВО) з метою дослідження навчального навантаження з фізики студентів зазначеного фаху в різних 3ВО; аналіз програм з фізики та дисциплін циклу професійної підготовки майбутніх фахівців з інформаційної безпеки з метою виявлення тих дисциплін з циклу професійної підготовки, під час вивчення яких використовуються знання, уміння і навички з курсу фізики; аналіз, порівняння, систематизація, узагальнення - під час встановлення міжпредметних зв' язків фізики з дисциплінами циклу професійної підготовки майбутніх фахівців з інформаційної безпеки, під час обговорення результатів дослідження та формулювання висновків роботи.

\section{РЕЗУЛЬТАТИ ДОСЛІДЖЕННЯ}

Аналіз наукових статей і навчально-методичних розробок, присвячених вивченню міжпредметних зв'язків, надає підстави зробити висновок, що єдиного підходу до визначення та класифікації міжпредметних зв'язків не існує. Узагальнивши результати дослідження інших авторів, у нашій недавній роботі (Іщенко \& Горбунович, 2020) запропоновано розглядати міжпредметні зв'язки як дидактичну категорію, що передбачає узгодження програм двох чи більше навчальних дисциплін, взаємне використання і взаємозбагачення спільних для них знань, умінь і навичок, а також методів, форм і засобів навчання. 
Проаналізувавши освітньо-професійні програми підготовки бакалаврів з інформаційної безпеки, що розроблені різними 3ВО, зокрема, Національним технічним університетом України (НТУУ) «КПІ ім. Ігоря Сікорського», Національним авіаційним університетом (НАУ), Національним університетом «Львівська політехніка» (НУ «ЛП»), Державним університетом телекомунікацій (ДУТ), Київським національним університетом (КНУ) ім. Тараса Шевченка, Харківським національним університетом радіоелектроніки (ХНУРЕ) і Національним транспортним університетом (НТУ), можна зробити висновок про те, що навчальна дисципліна «Фізика» відноситься до обов'язкових дисциплін циклу загальної підготовки майбутніх фахівців з інформаційної безпеки. У табл. 1 представлено навчальне навантаження 3 фізики майбутніх фахівців з інформаційної безпеки, що навчаються за спеціальністю 122 «Комп'ютерні науки» в НТУ та за спеціальністю 125 «Кібербезпека» в інших зазначених ЗВО. Як видно з табл. 1, в НТУУ «КПІ ім. Ігоря Сікорського», НАУ, НУ «ЛП» та ДУТ фізика вивчається студентами вказаної спеціальності протягом першого і другого семестрів. В КНУ ім. Тараса Шевченка і ХНУРЕ студентам читається односеместровий курс фізики протягом першого семестру, а в НТУ односеместровий курс фізики протягом третього семестру. При цьому кількість кредитів ЄКТС (1 кредит ЄКТС дорівнює 30 навчальних годин), що виділяються на вивчення фізики у вказаних 3ВО, різна - від 4 в НТУ до 10.5 в НТУУ «КПІ ім. Ігоря Сікорського». Отже, як видно з табл. 1, майбутнім фахівцям з інформаційної безпеки, що навчаються у зазначених університетах, читається різний за обсягом годин курс фізики. Відповідно, рівень підготовки з фізики в студентів, що навчаються у вказаних 3ВО, буде різним.

Таблиця 1

Навчальне навантаження з фізики майбутніх фахівців з інформаційної безпеки в різних зво

\begin{tabular}{|c|c|c|c|c|c|}
\hline 3BO & Спеціальність & $\begin{array}{c}\text { Освітньо-професійна } \\
\text { програма }\end{array}$ & $\begin{array}{c}\text { Кількість } \\
\text { кредитів } \\
\text { ЄКТС }\end{array}$ & $\begin{array}{l}\text { Семестр } \\
\text { вивчення }\end{array}$ & $\begin{array}{c}\text { Форма } \\
\text { підсумкового } \\
\text { контролю }\end{array}$ \\
\hline $\begin{array}{c}\text { НТУУ «КПІ } \\
\text { ім. Ігоря } \\
\text { Сікорського» }\end{array}$ & 125 «Кібербезпека» & $\begin{array}{l}\text { Системи, технології та } \\
\text { математичні методи } \\
\text { кібербезпеки }\end{array}$ & 10,5 & I, II & Залік, Екзамен \\
\hline HAY & 125 «Кібербезпека» & Аудит кібербезпеки & 10 & I, II & Залік, Залік \\
\hline нУ «лП» & 125 «Кібербезпека» & Кібербезпека & 8 & $\mathrm{I}, \mathrm{II}$ & Залік, Екзамен \\
\hline ДУт & 125 «Кібербезпека» & $\begin{array}{l}\text { Інформаційна та } \\
\text { кібернетична безпека }\end{array}$ & 7 & I, II & Залік, Екзамен \\
\hline $\begin{array}{c}\text { KHУ ім. Тараса } \\
\text { Шевченка }\end{array}$ & 125 «Кібербезпека» & Кібербезпека & 6 & 1 & Екзамен \\
\hline XHУPE & 125 «Кібербезпека» & $\begin{array}{l}\text { Управління } \\
\text { інформаційною } \\
\text { безпекою }\end{array}$ & 6 & 1 & Екзамен \\
\hline HTY & $\begin{array}{l}122 \text { «Комп'ютерні } \\
\text { науки» }\end{array}$ & $\begin{array}{l}\text { Інформаційна безпека в } \\
\text { комп'ютеризованих } \\
\text { системах }\end{array}$ & 4 & III & Екзамен \\
\hline
\end{tabular}

Для встановлення міжпредметних зв'язків фізики з дисциплінами циклу професійної підготовки майбутніх фахівців з інформаційної безпеки було проаналізовано програми відповідних навчальних дисциплін та вибрано ті з них, під час вивчення яких використовуються теми з тих чи інших розділів курсу фізики. Зв'язок фізики з дисциплінами циклу професійної підготовки зазначених фахівців представлено у табл. 2.

Так, як видно з табл. 2, під час вивчення дисципліни «Фізичні основи захисту інформації» розглядають фізичні поля об'єктів, джерела та властивості цих полів, явище електромагнітної індукції, фізичні процеси в коливальних контурах, явище резонансу, характеристики звукових хвильових процесів, фізичні ефекти акустоелектричного перетворення тощо. Для успішного опанування вказаної дисципліни необхідно мати міцні знання з таких розділів курсу фізики, як електрика, магнетизм, коливання і хвилі (як механічні, так і електромагнітні).

Під час вивчення дисципліни «Системи технічного захисту інформації» для формування вірної уяви про фізичні процеси, що відбуваються під час перетворення інформації в електронних пристроях і системах технічного захисту інформації, необхідно мати поняття про електромагнітне поле, електромагнітні хвилі та їх властивості, шкалу електромагнітних хвиль, моно- та поліхроматичне випромінювання, знати будову та принцип роботи лазера, типи лазерів, мати поняття про фізичні властивості і характеристики напівпровідників (див. табл. 2).

Для вдалого опанування навчальної дисципліни «Сигнали і процеси в системах захисту інформації» під час вивчення властивостей і характеристик сигналів і процесів у приладах і системах захисту інформації необхідно мати поняття про види коливань, фізичні величини, що характеризують коливання, знати, що таке акустичні хвилі та акустичний удар, розуміти фізичний механізм п'єзоелектричного ефекту, мати поняття про явище резонансу у колі змінного струму.

Під час вивчення дисципліни «Теорія інформації і кодування» необхідно знати, що таке ентропія та їі фізичний зміст, співвідношення Больцмана, другий принцип термодинаміки через поняття ентропії. Тобто, володіти на належному рівні відповідними темами з розділу молекулярна фізика і термодинаміка. Зокрема, у роботі (Кошкин, 2001) детально розглянуто базові поняття ентропії та інформації за Шенноном і відзначено їх важливу роль при вирішенні задач оптимального кодування під час передачі інформації по лініям зв'язку.

Необхідно відзначити, що до табл. 2 не включено такі загальнотехнічні дисципліни з циклу професійної підготовки майбутніх фахівців з інформаційної безпеки, як «Електротехніка і електроніка», "Основи автоматики», "Супутникові системи навігації зв'язку» та "Основи охорони праці та безпека людини», оскільки вказані дисципліни вивчаються не 
тільки майбутніми IT-фахівцями, а й переважною більшістю здобувачів вищої освіти, що навчаються за технічними спеціальностями. Однак, під час вивчення вищезазначених дисциплін також використовуються знання з різних розділів курсу фізики. Зокрема, під час опанування дисципліни «Електротехніка і електроніка» використовується практично весь теоретичний матеріал з електрики, магнетизму та електромагнітних коливань і хвиль, частково з оптики. Під час вивчення "Основ автоматики» використовується теоретичний матеріал з фізичних основ механіки, електрики, магнетизму, оптики. Під час вивчення дисципліни “Супутникові системи навігації зв'язку» необхідно мати базові знання з розділу фізичні основи механіки, а також знати ефект Доплера для використання його в доплерівському методі навігаційних визначень. Під час опанування дисципліни «Основи охорони праці та безпека людини» необхідні базові знання з атомної та ядерної фізики, зокрема, під час вивчення видів, властивостей та одиниць вимірювання іонізуючого випромінювання, доз опромінювання тощо.

Таблиця 2

Зв'язок фізики з дисциплінами циклу професійної підготовки майбутніх фахівців з інформаційної безпеки

\begin{tabular}{|c|c|c|}
\hline Дисципліна & Навчальна тема & Відповідна тема з курсу фізики \\
\hline \multirow[t]{7}{*}{$\begin{array}{l}\text { Фізичні основи } \\
\text { захисту інформації }\end{array}$} & Електричні поля об’єктів & $\begin{array}{l}\text { Електричне поле та його кількісні і графічні } \\
\text { характеристики }\end{array}$ \\
\hline & Магнітні поля об'єктів & $\begin{array}{l}\text { Магнітне поле та його кількісні і графічні } \\
\text { характеристики }\end{array}$ \\
\hline & Електромагнітна індукція & $\begin{array}{l}\text { Явище електромагнітної індукції. Закон } \\
\text { Фарадея }\end{array}$ \\
\hline & $\begin{array}{l}\text { Електромагнітні поля і хвилі. Екранування полів } \\
\text { електромагнітної природи. Реєстрація } \\
\text { електромагнітних полів }\end{array}$ & $\begin{array}{l}\text { Електромагнітне поле та його властивості. } \\
\text { Електромагнітні хвилі та їх властивості. } \\
\text { Шкала електромагнітних хвиль }\end{array}$ \\
\hline & $\begin{array}{l}\text { Фізичні процеси в коливальних контурах. Явище } \\
\text { резонансу }\end{array}$ & $\begin{array}{l}\text { Вимушені електромагнітні коливання. } \\
\text { Явище резонансу }\end{array}$ \\
\hline & $\begin{array}{l}\text { Характеристика звукових хвильових процесів. } \\
\text { Основи акустики }\end{array}$ & $\begin{array}{l}\text { Механічні (пружні) хвилі та їх } \\
\text { характеристики. Звукові хвилі. Шкала } \\
\text { механічних хвиль }\end{array}$ \\
\hline & $\begin{array}{l}\text { Фізичні ефекти акустоелектричного } \\
\text { перетворення }\end{array}$ & Основи акустоелектроніки \\
\hline \multirow{6}{*}{$\begin{array}{l}\text { Системи } \\
\text { технічного захисту } \\
\text { інформації }\end{array}$} & $\begin{array}{l}\text { Інфрачервоні та радіопроменеві бар'єри. } \\
\text { Радіохвильовий лінійний сповіщувач }\end{array}$ & $\begin{array}{l}\text { Шкала електромагнітних хвиль. Моно- та } \\
\text { поліхроматичне випромінювання }\end{array}$ \\
\hline & $\begin{array}{l}\text { Лазерні системи. Засоби зовнішнього } \\
\text { відеоспостереження }\end{array}$ & $\begin{array}{l}\text { Будова та принцип роботи лазера. Типи } \\
\text { лазерів }\end{array}$ \\
\hline & $\begin{array}{l}\text { Принципи виявлення напівпровідникових } \\
\text { елементів }\end{array}$ & Напівпровідники та їх властивості \\
\hline & $\begin{array}{l}\text { Паразитні електромагнітні випромінювання і } \\
\text { наведення }\end{array}$ & Електромагнітні хвилі та їх властивості \\
\hline & $\begin{array}{l}\text { Обмеження малих амплітуд. Односпрямована } \\
\text { передача сигналів }\end{array}$ & $\begin{array}{l}\text { Фізичні величини, що характеризують } \\
\text { хвилі }\end{array}$ \\
\hline & Засоби екранування електромагнітних полів & Електромагнітне поле та його властивості \\
\hline \multirow[t]{4}{*}{$\begin{array}{l}\text { Сигнали і процеси } \\
\text { в системах захисту } \\
\text { інформації }\end{array}$} & $\begin{array}{l}\text { Класифікація процесів і сигналів. } \\
\text { Сигнали та їх основні характеристики }\end{array}$ & $\begin{array}{l}\text { Види коливань. Гармонічні коливання. } \\
\text { Фізичні величини, що характеризують } \\
\text { коливання }\end{array}$ \\
\hline & Пристрої на поверхневих акустичних хвилях & $\begin{array}{l}\text { Поверхневі акустичні хвилі. Ударні хвилі та } \\
\text { акустичний удар }\end{array}$ \\
\hline & П'єзоелектричні резонатори & $\begin{array}{l}\text { П'єзоелектричний ефект та його } \\
\text { застосування }\end{array}$ \\
\hline & $\begin{array}{l}\text { Резонансні явища в колах синусоїдального } \\
\text { струму }\end{array}$ & $\begin{array}{l}\text { Змінний електричний струм. Резонанс у } \\
\text { колі змінного струму }\end{array}$ \\
\hline $\begin{array}{l}\text { Теорія інформації і } \\
\text { кодування }\end{array}$ & $\begin{array}{l}\text { Ентропія як міра невизначеності та кількості } \\
\text { інформації. Безумовна та умовна ентропія. } \\
\text { Ентропія об'єднання джерел повідомлень }\end{array}$ & $\begin{array}{l}\text { Ентропія. Фізичний зміст ентропії. } \\
\text { Співвідношення Больцмана. Другий } \\
\text { принцип термодинаміки через поняття } \\
\text { ентропії }\end{array}$ \\
\hline
\end{tabular}

\section{ОБГОВОРЕННЯ}

3 проведеного аналізу освітньо-професійних програм підготовки бакалаврів з інформаційної безпеки виявлено, що під час освітнього процесу в усіх зазначених зВО (див. табл. 1) враховуються хронологічні міжпредметні зв'язки фізики з дисциплінами циклу професійної підготовки вказаних IT-фахівців, які забезпечують узгоджене викладання зазначених навчальних дисциплін у часі, відповідно до потреб кожної з них. Дійсно, фізику вивчають, як правило, протягом перших двох семестрів (як виняток в НТУ - протягом третього семестру), а дисципліни циклу професійної підготовки починають вивчати з другого курсу. Отже, студенти набувають відповідних загальних і професійних компетентностей з фізики перед вивченням дисциплін циклу професійної підготовки. 
Аналіз програм з фізики та дисциплін циклу професійної підготовки майбутніх фахівців з інформаційної безпеки показав, що для успішного опанування ряду вказаних дисциплін необхідно мати міцні знання з наступних розділів курсу фізики: електрики, магнетизму, коливань та хвиль (механічних і електромагнітних), оскільки переважна більшість тем із зазначених розділів курсу фізики використовуються під час вивчення ряду дисциплін циклу професійної підготовки вказаних фахівців. Також необхідно мати базові знання з таких розділів курсу фізики, як фізичні основи механіки, молекулярна фізика і термодинаміка, оптика, атомна та ядерна фізика. Крім того, необхідно знати основи квантової фізики, оскільки саме закони квантової фізики використовуються в квантовій криптографії, зокрема, в методі квантового розподілу ключів, який, як відзначено в роботі (Sharmini Pillay, 2015), може стати єдиним безпечним методом шифрування даних. Таким чином, для вдалого опанування ряду дисциплін циклу професійної підготовки майбутніх фахівців 3 інформаційної безпеки необхідно на належному рівні володіти знаннями, уміннями і навичками з усіх розділів курсу фізики рівня технічного університету.

Необхідно відзначити, що врахування міжпредметних зв'язків фундаментальних дисциплін з дисциплінами професійної підготовки під час освітнього процесу в ЗВО відіграє важливу роль у підвищенні ефективності науковотеоретичної та практичної підготовки студентів, суттєвою особливістю якої є оволодіння ними узагальненими навичками пізнавальної діяльності (Козлов, Томашевська \& Кузнєцов, 2018). Останнє призводить до схильності студентів логічно мислити, систематизувати і узагальнювати набуті знання. Отже, врахування міжпредметних зв'язків фізики 3 дисциплінами циклу професійної підготовки майбутніх фахівців з інформаційної безпеки дозволяє ефективніше використовувати знання, уміння і навички з курсу фізики під час вивчення дисциплін циклу професійної підготовки, що сприяє більш глибокому засвоєнню студентами зазначених дисциплін.

\section{ВИСНОВКИ ТА ПЕРСПЕКТИВИ ПОДАЛЬШОГО ДОСЛІДЖЕННЯ}

Таким чином, за результатами проведеного аналізу освітньо-професійних програм підготовки бакалаврів 3 інформаційної безпеки, що розроблені різними ЗВО, виявлено, що під час освітнього процесу враховуються хронологічні міжпредметні зв'язки фізики з дисциплінами циклу професійної підготовки вказаних фахівців, які забезпечують узгоджене викладання зазначених навчальних дисциплін у часі. За результатами аналізу програм з фізики та дисциплін циклу професійної підготовки майбутніх фахівців з інформаційної безпеки встановлено, що для успішного опанування ряду дисциплін циклу професійної підготовки необхідно мати належний рівень знань, умінь і навичок з усіх розділів курсу фізики, що читається студентам технічних спеціальностей зВО. Особливу увагу під час вивчення курсу фізики необхідно приділити розгляду таких розділів, як електрика, магнетизм, механічні та електромагнітні коливання і хвилі, оскільки переважна більшість тем з вказаних розділів фізики використовуються під час вивчення ряду дисциплін циклу професійної підготовки зазначених фахівців. Встановлено, що врахування міжпредметних зв'язків фізики з дисциплінами циклу професійної підготовки майбутніх фахівців з інформаційної безпеки сприяє більш глибокому засвоєнню студентами вказаних дисциплін. Останнє призводить до підвищення успішності студентів та їх мотивації до навчання, що, в свою чергу, підвищує ефективність освітнього процесу в ЗВО.

Наступну роботу планується присвятити встановленню ролі задач міжпредметного змісту під час проведення практичних занять з фізики і математики в технічному університеті.

\section{Список використаних джерел}

1. Безуглий Д.С. Інформаційна безпека України: огляд останніх тенденцій. Фізико-математична освіта, 2018. Вип. 2 (16). С. 13-17. DOI: 10.31110/2413-1571-2018-016-2-002.

2. Дідик А.О. Реалізація міждисциплінарних зв'язків у процесі навчання електротехніки та електроніки. Наукові записки. Серія: Педагогічні науки, 2019. Вип. 143. С. 80-87. DOI: 10.31392/NZ-npu-143.2019.10.

3. Ільніцька К.С. Робототехніка як об'єкт вивчення майбутніми учителями фізики в межах дисципліни «Основи сучасної електроніки». Збірник наукових праць Уманського державного педагогічного університету ім. Павла Тичини. Умань, 2020. Вип. 1. С. 80-86.

4. Іщенко Р.М., Горбунович І.В. Міжпредметні зв'язки фізики і математики під час викладання фізичних основ механіки студентам технічного університету. Фізико-математична освіта, 2020. Вип. 1 (23). Ч. 2. C. 39-44. DOI: 10.31110/24131571-2020-023-1-2-006.

5. Іщенко Р.М., Ісаєнко Г.Л. Аналіз загальноосвітнього рівня предметної компетентності з фізики здобувачів вищої освіти технічного університету за результатами вхідного контролю. Збірник наукових праць Уманського державного педагогічного університету ім. Павла Тичини. Умань, 2020. Вип. 2. Ч. 2. С. 68-78.

6. Козлов В.В., Томашевська Т.В., Кузнєцов М.І. Використання міждисциплінарних зв'язків при підготовці майбутніх фахівців зі статистики. Статистика України, 2018. № 1. С. 52-60. DOI: 10.31767/su.1(80).2018.01.07.

7. Коржова О.В. Теоретичні аспекти міжпредметних зв'язків математичних дисциплін з дисциплінами циклу професійної підготовки майбутніх фахівців із організації інформаційної безпеки. Фізико-математична освіта, 2017. Вип. 2 (12). С. 89-93.

8. Кошкин Г.М. Энтропия и информация. Соросовский образовательный журнал. Серия: Математика, 2001. Том 7, № 11. C. 122-127.

9. Матвійчук О.В., Сергієнко В.П., Подласов С.О. Реалізація міжпредметних зв'язків фізики та інформатики на основі вивчення комп'ютерного моделювання фізичних процесів. Збірник наукових праць Кам'янець-Подільського національного університету ім. Івана Огієнка. Серія: Педагогічна. Кам'янець-Подільський, 2008. Вип. 14. С. 24-26.

10. Рой Я.В., Мазур Н.П., Складанний П.М. Аудит інформаційної безпеки - основа ефективного захисту підприємства. Кібербезпека: освіта, наука, техніка, 2018. № 1 (1). С. 86-93.

11. Сопілко І.М. Становлення інформаційного суспільства та інформаційні загрози в мережі інтернет. Юридичний вісник, 2017. № 3 (44). С. 61-69. 
12. Lei Bao, Kathleen Koenig. Physics education research for $21^{\text {st }}$ century learning. Disciplinary and Interdisciplinary Science Education Research, 2019. № 1. P. 2-12. DOI: 10.1186/s43031-019-0007-8.

13. Richard Van Noorden. Interdisciplinary research by the numbers. Nature, 2015. Vol. 525. P. 306-307. DOI: 10.1038/525306a.

14. Sharmini Pillay. How quantum physics is improving data security. World Economic Forum: Agenda, 20 August 2015. URL: https://www.weforum.org/agenda/2015/08/how-quantum-physics-is-improving-data-security/ (Last accessed: 20.12.2020).

15. Zeynep Baskan, Nedim Alev, Isik Saliha Karal. Physics and mathematics teachers' ideas about topics that could be related or integrated. Procedia Social and Behavioral Sciences, 2010. № 2. P. 1558-1562.

\section{References}

1. Bezuhlyy, D.S. (2018). Informatsiyna bezpeka Ukrayiny: ohlyad ostannikh tendentsiy [Information security of Ukraine: review of recent trends]. Fizyko-matematychna osvita - Physical and Mathematical Education, 2 (16), 13-17. DOI: 10.31110/24131571-2018-016-2-002 [in Ukrainian].

2. Didyk, A.O. (2019). Realizatsiya mizhdystsyplinarnykh zvyazkiv u protsesi navchannya elektrotekhniky ta elektroniky [Implementation of interdisciplinary connections in the process of teaching electrical engineering and electronics]. Naukovi zapysky. Seriya: Pedahohichni nauky - Scientific notes. Series: Pedagogical Sciences, 143, 80-87. DOI: 10.31392/NZ-npu143.2019.10 [in Ukrainian].

3. IInitska, K.S. (2020). Robototekhnika yak obyekt vyvchennya maybutnimy uchytelyamy fizyky v mezhakh dystsypliny "Osnovy suchasnoyi elektroniky"[Robotics as an object of study by future physics teachers within the discipline "Fundamentals of Modern Electronics"]. Zbirnyk naukovykh prats Umanskoho derzhavnoho pedahohichnoho universytetu im. Pavla Tychyny Collection of scientific works of Uman state pedagogical university named after P. Tychyna, 1, 80-86 [in Ukrainian].

4. Ishchenko, R.M. \& Gorbunovich, I.V. (2020). Mizhpredmetni zvyazky fizyky i matematyky pid chas vykladannya fizychnykh osnov mekhaniky studentam tekhnichnoho universytetu [Intersubject connections of physics and mathematics at teaching the physical fundamentals of mechanics to students of technical university]. Fizyko-matematychna osvita - Physical and Mathematical Education, 1 (23), 2, 39-44. DOI: 10.31110/2413-1571-2020-023-1-2-006 [in Ukrainian].

5. Ishchenko, R.M. \& Isaienko, G.L. (2020). Analiz zahalnoosvitnoho rivnya predmetnoyi kompetentnosti z fizyky zdobuvachiv vyshchoyi osvity tekhnichnoho universytetu za rezultatamy vkhidnoho kontrolyu [Analysis of the general level of subject competence from physics of technical university students based on the results of the entrance control]. Zbirnyk naukovykh prats Umanskoho derzhavnoho pedahohichnoho universytetu im. Pavla Tychyny - Collection of scientific works of Uman state pedagogical university named after $P$. Tychyna, 2 (2), 68-78 [in Ukrainian].

6. Kozlov, V.V., Tomashevska, T.V. \& Kuznyetsov, M.I. (2018). Vykorystannya mizhdystsyplinarnykh zvyazkiv pry pidhotovtsi maybutnikh fakhivtsiv zi statystyky [Use of interdisciplinary links in the training of the future specialists in statistics]. Statystyka Ukrayiny - Statistics of Ukraine, 1, 52-60. DOI: 10.31767/su.1(80).2018.01.07 [in Ukrainian].

7. Korzhova, O.V. (2017). Teoretychni aspekty mizhpredmetnykh zvyazkiv matematychnykh dystsyplin z dystsyplinamy tsyklu profesiynoyi pidhotovky maybutnikh fakhivtsiv iz orhanizatsiyi informatsiynoyi bezpeky [Theoretical aspects of interdisciplinary communications between mathematical disciplines and disciplines of professional training of future specialists in organization of information security]. Fizyko-matematychna osvita - Physical and Mathematical Education, 2 (12), 89-93 [in Ukrainian].

8. Koshkin, G.M. (2001). Entropiya i informatsiya [Entropy and information]. Sorosovskiy obrazovatelnyy zhurnal. Seriya: Matematika - Soros Educational Journal. Series: Mathematics, 7 (11), 122-127 [in Russian].

9. Matviychuk, O.V., Serhiyenko, V.P. \& Podlasov, S.O. (2008). Realizatsiya mizhpredmetnykh zvyazkiv fizyky ta informatyky na osnovi vyvchennya kompyuternoho modelyuvannya fizychnykh protsesiv [Implementation of interdisciplinary connections between physics and informatics based on the study of computer modeling of physical processes]. Zbirnyk naukovykh prats Kam'yanets-Podilskoho natsionalnoho universytetu im. Ivana Ohiyenka. Seriya: Pedahohichna - Collection of scientific works of Kamenets-Podilsky national university named after Ivan Ogienko. Series: Pedagogical, 14, 24-26 [in Ukrainian].

10. Roy, Ya.V., Mazur, N.P. \& Skladannyy, P.M. (2018). Audyt informatsiynoyi bezpeky - osnova efektyvnoho zakhystu pidpryyemstva [Audit of information security is the basis of effective protection of the enterprise]. Kiberbezpeka: osvita, nauka, tekhnika - Cybersecurity: Education, Science, Technique, 1 (1), 86-93 [in Ukrainian].

11. Sopilko, I.M. (2017). Stanovlennya informatsiynoho suspilstva ta informatsiyni zahrozy v merezhi internet [The emergence of the information society and information threats in the Internet]. Yurydychnyy visnyk - Legal Bulletin, 3 (44), 61-69 [in Ukrainian].

12. Lei Bao \& Kathleen Koenig. (2019). Physics education research for $21^{\text {st }}$ century learning. Disciplinary and Interdisciplinary Science Education Research, 1, 2-12. DOI: 10.1186/s43031-019-0007-8 [in English].

13. Richard Van Noorden. (2015). Interdisciplinary research by the numbers. Nature, 525, 306-307. DOI: 10.1038/525306a [in English].

14. Sharmini Pillay. (2015). How quantum physics is improving data security. World Economic Forum: Agenda, 20 August 2015. Retrieved from https://www.weforum.org/agenda/2015/08/how-quantum-physics-is-improving-data-security/ [in English].

15. Zeynep Baskan, Nedim Alev \& Isik Saliha Karal. (2010). Physics and mathematics teachers' ideas about topics that could be related or integrated. Procedia Social and Behavioral Sciences, 2, 1558-1562 [in English]. 


\section{INTERSUBJECT CONNECTIONS OF PHYSICS WITH DISCIPLINES OF THE CYCLE OF PROFESSIONAL TRAINING OF FUTURE INFORMATIONAL SECURITY SPECIALISTS \\ Ali Al-Ammouri, Ruslan Ishchenko \\ National Transport University, Ukraine}

Abstract.

Formulation of problem. The rapid development of information technology, the formation and development of the informational society cause the question of informational security. Accordingly, the training of qualified informational security specialists is currently relevant. It should be noted that the level of training of these specialists largely depends on their proper study of fundamental disciplines, in particular, physics. Therefore, this paper is devoted to establishing intersubject connections of physics with disciplines of the cycle of professional training of future informational security specialists.

Materials and methods. To achieve the purpose of the work, the following methods were used: analysis and systematization - during the review of scientific publications on the chosen subject of research; analysis, comparison, systematization, generalization - during the establishing of intersubject connections of physics with disciplines of the cycle of professional training of future informational security specialists, discussing the results of research and formulating the conclusions of the work.

Results. An analysis of educational and professional training programs of bachelors in informational security, developed by various higher education institutions, revealed that during the educational process chronological intersubject connections of physics with disciplines of the cycle of professional training are taken into account. The programs in physics and disciplines of the cycle of professional training of these specialists are analyzed and those of them are selected, during the study of which topics from certain sections of the physics course are used. The connection between physics and the disciplines of the cycle of professional training of future informational security specialists has been established.

Conclusions. According to the results of the analysis of programs in physics and disciplines of the cycle of professional training of future informational security specialists it is established that to successfully study a number of disciplines of the cycle of professional training it is necessary to have the appropriate level of knowledge, skills and abilities in all sections of the physics course of the technical university level. It is established that taking into account the intersubject connections of physics with the disciplines of the cycle of professional training of these specialists leads to increased student achievement and motivation to study, which, in turn, increases the efficiency of the educational process in higher education institutions.

Key words: intersubject connections, physics course, disciplines of professional training, informational security specialist, technical university. 